\title{
Access to justice through clinical legal education: A way forward for good governance and development
}

\author{
Oluyemisi Bamgbose* \\ Professor of Criminal Law and Criminology, Faculty of law, University of \\ Ibadan, Nigeria
}

\begin{abstract}
Summary
Access to justice is a fundamental right that ought to be universal, but a lack of effective access to justice is frequently identified as a major barrier to realising human rights. This relates especially to women. Nigerian women are not sufficiently protected by the legal system. Women in Africa, generally, and in Nigeria, in particular, face numerous barriers that hinder their access to legal services and assistance from legal institutions that are set up to redress wrongs. Under the Constitution of the Federal Republic of Nigeria 1999, it is the duty of government to ensure that all citizens have access to justice. Legal aid clinics have in the last decade developed alongside other governmental legal services. The article discusses the evolution of legal clinics in educational institutions and by non-governmental organisations in Nigeria and focuses in particular on how access to justice through the intervention of the Women's Law Clinic, University of Ibadan, has impacted on governance and development.
\end{abstract}

Key words: Access to justice; clinical legal education; good governance; development

\section{Introduction}

Access to justice is a fundamental right that ought to be universal, but a lack of effective access to justice is frequently identified as a major barrier to realising human rights. This relates especially to women. In Nigeria, there is marked social inequality. Many of ordinary citizens live in poverty, deprived of the basic necessities of life, such as food,

* LLB LLM (Lagos); oluyemisibamgbose@hotmail.com 
shelter, health care, water, land and livelihood, and generally have less access to the protection of the state. ${ }^{1}$

Although the Constitution of the Federal Republic of Nigeria, 1999, provides for legal aid or free legal services, ${ }^{2}$ access to justice remains a myth rather than a reality for many citizens, particularly the indigent and vulnerable. Section 46(4) of the 1999 Nigerian Constitution provides that the National Assembly makes laws to provide for financial assistance to any indigent citizen whose fundamental rights are violated; with a view to enabling him or her to engage the services of a legal practitioner. While this institution exists, the funding for it is inadequate to meet the needs of the people.

In 1976, the Legal Aid Act was enacted. ${ }^{3}$ The Act, which entered into force on 2 May 1977, provided in section 7(1) for legal assistance in respect of capital offences and serious criminal cases. This Act was amended by the 1990 Legal Aid Act ${ }^{4}$ and the 2004 Legal Aid Act, ${ }^{5}$ which extended the cover to criminal cases such as malicious and unlawful wounding, assault occasioning harm, affray, stealing, rape and civil claims in respect of accidents and civil claims to cover cases involving the infringement of fundamental human rights under chapter IV of the Constitution. All the above-mentioned laws have been repealed by the 2011 Legal Aid Act. ${ }^{6}$

Section 8 of the 2011 Act provides that the Legal Aid Council created under the Act will provide legal aid, advice and access to justice in three broad areas. These areas are criminal defence service; advice, assistance and legal representation in court in civil matters; and community legal services. These services are based on merit and the level of indigence of the parties. Section 9 of the 2011 Act provides for a general legal aid fund from which the Legal Aid Council can draw funds. The source of the funds for the Council is to be appropriated annually by the National Assembly pursuant to section 46 of the Constitution of the Federal Republic of Nigeria. ${ }^{7}$ At the inauguration of the Legal Aid Council, the Attorney-General of the Federation and Minister of Justice urged the members to provide greater access to justice, free legal services and advice to indigent Nigerians who otherwise could not afford such services in the event of a violation of their rights. He further stated that with this increased mandate, there would be an improvement in the administration of

1 OECD Guideline Series 'Participatory development and good governance development co-operation' 1995 http://www.oecd.org/dac/governance-develop ment/31857685.pdf (accessed 22 June 2014).

Sec 46(1).

Legal Aid Act 56 of 1976

Laws of the Federation of Nigeria Cap 2051990.

Laws of the Federation of Nigeria Cap L9 2004.

Act 17 of 2011.

Sec 9(a) Act 17 of 2011. 
justice in Nigeria. ${ }^{8}$ Despite these laudable laws, there is no doubt that the funding for legal aid in Nigeria is inadequate. There has been a call for review of the 2011 Act due to challenges faced by the Council, which include funding, inadequate infrastructure and an insufficient number of lawyers. ${ }^{9}$ The Chairperson recommended the creation of an access to justice fund that will enable the Council to receive donations from corporate organisations and individuals as one way of improving the funding. ${ }^{10}$ The above discussion shows that there are existing laws to provide access to justice. However, the question is how efficient are the laws in reality.

Many developing countries suffer from weak legal and judicial systems. Women in Africa, generally, and in Nigeria, in particular, face numerous barriers that hinder their access to legal services and assistance from legal institutions that are set up to redress wrongs. Although the African Charter on Human and Peoples' Rights (African Charter) ${ }^{11}$ provides for the right of access to justice for African people in general, and the Protocol to the African Charter on Human and Peoples' Rights on the Rights of Women in Africa (African Women's Protocol) ${ }^{12}$ provides for the right of access to justice to women in Africa in particular, Nigerian women are still not sufficiently protected by the legal system. The fact that the barriers exist suggests that legal institutions in Nigeria are weak and ineffective.

In Nigeria, there are institutions, such as Legal Aid, established by the government, and there are also those set up by the different civil societies. The 1999 Nigerian Constitution ${ }^{13}$ provides for legal aid or free legal services. However, access to justice remains a myth rather than a reality for many citizens, particularly the indigent and vulnerable. The existing legal aid scheme is not only inadequate and deficient, but also limited in scope.

Law clinics at law faculties across Nigeria serve to fill the gap not adequately addressed by governmental legal aid programmes. There are 18 established law clinics in Nigeria. The introduction of clinical legal education was launched in Nigeria in 2005 with four pilot law

8 Y Ali 'Provide more access to justice for Nigerians, AGF tasks Legal Aid Council' The Nation 22 June 2012 http://www.thenationonlineng.net/2011/index.php/ mobile/news/51311-provide-more-access-to-justice-for-nigerians-agf-tasks-legalaid-council (accessed 22 June 2014).

9 Legal Aid Council of Nigeria 'Legal Aid Council call for review of the Legal Aid Act $2011^{\prime}$ (2012) http://legalaidcouncil.gov.ng/index.php?option=com_content\& view $=$ article\&id=101\%3Alegal-aid-council-calls-for-review-of-2011-act\&ltemid= 145 (accessed 11 June 2014).

10 n 8 above.

11 Adopted on 12 June 1981, entered into force 21 October 1986, http://www. achpr.org/instruments/achpr/ 18 (accessed 25 July 2015) arts $3 \& 7$.

12 Adopted 7 November 2003, entered into force 25 November 2005, http:// www.achpr.org/instrument/women-protocol/ (accessed 25 July 2015) art 8.

13 Sec 46(1). 
clinics, which were later increased to six in 2007, ten in 2008 and in 201518 law clinics. ${ }^{14}$ These clinics are ABSU Law Clinic, Abia State University, Abia State; AKUNGBA Law Clinic, Adekunle Ajasin University, Ondo State; MAIDUGURI Law Clinic, University of Maiduguri, Bornu State; UNIUYO Law Clinic, University of Uyo, Ebonyi State; EBSU Law Clinic, Ebonyi State University, Uyo; AAU Law Clinic, Ambrose Ali University, Ekpoma, Edo State; Women's Law Clinic (WLC) University of Ibadan, Ibadan, Oyo State; UNIABUJA Law Clinic, University of Abuja, Abuja; ABU Law Clinic, Ahmadu Bello University, Zaria, Kaduna State; NSUK Law Clinic, Nasarawa State University, Keffi, Nasarawa State; UNEC Law Clinic, University of Nigeria, Enugu Campus, Enugu State; OOU Law Clinic, Olabisi Onabanjo University, Ago Iwoye, Ogun State; Community Law Clinic, University of Ilorin, llorin, Kwara State; Nigerian Law School Law Clinic, Law School Headquarters, Bwari, Abuja; and Legal Advice Centre, Nigerian Law School, Augustine Nnamani Campus, Agbani, Enugu State. These clinics, including the WLC, the only specialised clinic for women in Nigeria, are filling the wide gap created by inadequate governmental institutions set up to redress injustices. Legal clinics are having an impact on the Nigerian administration of justice.

There is no doubt that there is a correlation between access to justice, governance and development. Governance is important for development performance. It is the duty of government to ensure that all citizens have access to justice. According to a statement in the United Nations Millennium Project: ${ }^{15}$

There is no excuse for any country, no matter how poor, to abuse its citizens, deny them equal protection of the law or leave them victims of corruption, mismanagement or economic irrationality.

In the course of this work it was noted that, although there is significant literature on governance and development, not much has been done about the link between the advantages of legal clinics developed as a result of clinical legal education, good governance and development in Nigeria. The findings discussed in this article were the result of a qualitative study of a random selection of cases handled in the Women's Law Clinic at the University of Ibadan, Nigerian laws and statutes and scholarly materials.

\section{Access to justice: Background and definition}

Access to justice is the hallmark of a civilised society. It is of paramount importance and a fundamental right that ought to be

14 Network of University Legal Aid Institutions (NULAI Nigeria) 2008-2012 Activities Report (2013) 4.

15 United Nations Millennium Project 2002-2006 http://www.unmillenniumpro ject.org/reports/why8.htm (accessed 2 June 2014). 
universal. It is a need and not a luxury. Robins ${ }^{16}$ traced the origin of the concept of access to justice to an Italian jurist, Mairo Cappelleti, who stated that 'it is the most basic requirement, the most basic human right of a system which purports to guarantee legal rights'. ${ }^{17}$

It is generally agreed that the concept of access to justice is vague. It is also agreed that it has no singular meaning. ${ }^{18}$ According to Oputa, ${ }^{19}$ the concept can be viewed from a narrow or wider sense. In the narrow sense, it refers to access to the law court. It is believed that this is a precondition for access to justice. ${ }^{20}$ According to Ojukwu, ${ }^{21}$ access to justice is a concept that embraces the nature, mechanism and even the quality of justice obtainable in a society as well as the place of the individual within the judicial matrix. It is also an important barometer for assessing not only the rule of law in any society, but also the quality of governance in that society. Access to justice is the ability of people to seek and obtain a remedy through formal or informal institutions of justice for grievances in compliance with human rights standards. ${ }^{22}$

According to the Global Alliance Against Traffic in Women (GAATW), access to justice means access to a fair, respectful and efficient legal process, either through judicial, administrative or other public processes, resulting in a just and adequate outcome. ${ }^{23}$ It involves legal protection, legal awareness, legal aid and counsel adjudication and enforcement. There is no access to justice where members of a society (especially marginalised groups) fear the system, see it as alien and do not access it, where the justice system is financially inaccessible, where individuals have no lawyers, where they do not have information or knowledge regarding rights, or where there is a weak justice system. ${ }^{24}$ Access to justice entails that a population understand their rights and the means of claiming such

16 Robin 'Access to justice is a fine concept: What does it mean in view of the cut to legal aid?' The Guardian 6 October 2011 https//www.theguardian.com/law/2011/ oct/06/access-to-justice-legal-aid-cut (accessed 27 May 2014).

17 M Cappelletti \& G Bryant Access to justice. A world survey (1978) cited in Robin (n 16 above).

18 P Morris et al Social needs and legal action (1973).

19 CA Oputa Rights in the political and legal culture of Nigeria (1989).

$20 \mathrm{CN}$ Okogbule 'Access to justice and human rights protection in Nigeria: Problems and prospects' (2005) 3 Sur - International Journal on Human Rights 96-97.

21 E Ojukwu et al Handbook on Prison Pre-Trial Detainee Law Clinic (2012).

22 United States Institute of Peace 'Necessary conditions: Access to justice' http:// www.usip.org/guiding-principles-stabilization-and-reconstruction-the-web-version /7-rule-law/access-justice (accessed 6 June 2014).

23 'Access to justice. The global alliance against traffic in women' http:// www.gaatw.org/index.php?option=com_content\&view=article\&id=446:access-tojustice\&catid=157: what-we-do\&Itemid=12 (accessed 22 June 2014).

24 United States Institute of Peace (n 22 above). 
rights. ${ }^{25} \mathrm{It}$, therefore, contributes to an enabling environment for achieving the Millennium Development Goals (MDGs).

The lack of effective access to justice is a major barrier to people to realise their human rights. The rule of law is an essential factor for the effective functioning of society and the economy. It has been stated that a predictable and accessible legal environment, with an objective, reliable and independent judiciary, is an essential factor for good governance and the realisation of human rights. ${ }^{26}$ Injustice, inequity and inefficiencies in the legal system of a country obstruct development.

Apart from poverty, other factors militating against access to justice include mass illiteracy, ignorance and financial incapacity, corruption, delays in the court system, backlogs, and uncertainty associated with expected court outcomes, lawlessness of the executive arm of government and its agents, procedural rules (criminal and civil) and constitutional limitations. ${ }^{27}$

$\operatorname{Ladan}^{28}$ attributes inadequate and unequal access to justice to discriminatory laws, and expensive, slow and complex legal processes.

The lack of effective access to justice particularly affects low-income populations and vulnerable persons in society. Women and children, in particular, are affected as they are not adequately protected by the legal system. Women's access to justice is of paramount importance in ensuring political and economic development in any society. The reality is that there are gross discriminatory practices against women which greatly limit their access to justice. In a Consortium Development Partnership Report, ${ }^{29}$ it was noted that the practices mentioned above are sanctioned by various institutions, including the formal legal system.

A question that arises from the above discussion is whether there is a link between access to justice, good governance and development.

25 United Nations 'Access to justice in the promotion and protection of the rights of indigenous peoples' (2013) http://www.ohchr.org/Documents/Issues/IPeoples/ EMRIP/Session6/A-HRC-EMRIP-2013-2_en.pdf (accessed 6 June 2014).

26 OECD Guideline Series ( $\mathrm{n} 1$ above).

27 O Bamgbose et al 'Community lawyering - An intervention of the University of Ibadan Women's Law Clinic in the case of stray bullet killings at Arulogun Idi-Omo community - A case study' (2012) 1 African Journal of Clinical Legal Education and Access to Justice.

28 MT Ladan Justice sector reform: Imperatives for a democracy (2012) http://www. abu.edu.ng/publications/20121110-134151_3901.Doc (accessed 22 June 2014).

29 O Bamgbose et al 'Final report on access to justice and human rights for women project under CDP 11' (2011) Council for Development Social Science Research in Africa under an Initiative of the Consortium For Development Partnerships, November 2011. 


\section{Good governance: Definition and discourse}

The World Bank ${ }^{30}$ defines governance as 'the method through which power is exercised in the maintenance of a country's political, economic and social resources for development'. Governance is the exercise of economic, political and administrative authority to manage a country's affairs at all levels. It is said to comprise the mechanisms, processes and institutions through which citizens and groups articulate their interests, exercise their legal rights, meet their obligations and mediate their differences. ${ }^{31}$ Good governance entails, amongst other things, a legal framework for development which includes justice and respect for human rights and liberties. ${ }^{32}$

Where good governance prevails, the voices of the poor and vulnerable are heard. A characteristic of good governance is participation. This includes access to judicial and administrative redress. Fair, responsive and effective institutions and the protection of human rights are components of good governance. The ability to participate should exist regardless of social or economic status. Good governance, therefore, suggests that the voices of the poorest and most vulnerable should be heard and they should receive just, fair and equitable treatment. ${ }^{33}$

While good governance promotes equity and sustainable development, bad governance is a barrier to economic development and leads to the collapse of a nation. Weak governance affects the delivery of services and benefits to those who need them most. ${ }^{34}$

This article adopts the simple definition of governance, as stated by De Vries, ${ }^{35}$ that 'governance is the conduct of government'. One of the sets of values guiding the working of a government are human rights principles, one of which is access to justice. They inform the content of good governance. ${ }^{36}$ Good governance implies a willingness of the state to protect the weak and promote the interests of the poor.

30 World Bank Governance (1993).

31 United Nations Development Programme Human Development Report http:// hdr.undp.org/en.humandev (accessed 6 June 2014).

32 Ladan (n 28 above).

33 United Nations Development Programme (n 31 above).

34 UNDP Governance for sustainable human development. UNDP Policy Document (1997) http:// reform.gov.bb/page/good-governance.pdf (accessed 6 June 2014).

$35 \mathrm{M}$ de Vries 'The challenges of good governance' (2013) 18 The Innovation Journal: The Public Sector Innovation 4.

36 Office of the UN High Commissioner for Human Rights Good governance practices for the protection of human rights (2007), http://www.ohchr.org/documents/ publications/GoodGovernance.pdf (accessed 6 June 2014). 


\section{Development: Definition}

The use of the term 'development' in this article is that of the Collins English dictionary, meaning 'growth, progress or advancement'. ${ }^{37}$ Development for this purpose, therefore, suggests a systematic rather than a random change. It is used in terms of both infrastructural and human development in respect of the wellbeing of persons. The article adopts a simple non-technical definition for the use of the term 'human development'. However, a cue is taken from the definition attributed to Sen, which states that 'human development is basically advancing the richness of human life and it is discussed in relation to the human right of access to justice' ${ }^{38}$ The question then arises as to whether improving and/or removing barriers to access to justice will advance the human development of women in Nigeria.

\section{Development of clinical legal education}

Clinical legal education is a multi-disciplinary, multi-purpose education which can develop the human resources and idealism needed to strengthen the legal system. ${ }^{39}$ A lawyer, the product of such education, would be able to contribute to national development and social change in a constructive manner. ${ }^{40}$ It is a new pattern of legal education, as distinguished from the traditional method of education which focused on theory and provided minimal opportunity for law students to learn and apply practical problemsolving skills.

The traditional pedagogical style based on formality, theory and lecturing methods was the dominant teaching method in most law faculties of African universities for many years. This did not allow law students to interact with live clients or to acquire practical legal skills.

Clinical legal education introduces a method of instruction whereby students get the opportunity to apply the theoretical aspect of law training to real-life situations. Law students undergoing clinical legal education are taught the 'how to' of the law in order to address injustices in society. Through the establishment of law clinics under clinical education programmes, law students are exposed to societal responsibilities in addition to professional duties, and also to the fact that they meet the legal needs of the poor and underrepresented in society.

37 C Harper Collins English dictionary - Complete and unabridged (2003).

38 Cited in the United Nations Development Programme (n 31 above).

39 AHM Kamal \& S Talukder 'Diversification of legal education: Understanding the dichotomy of practical and theoretical knowledge' (2010) 4 ASA University Review 117.

40 As above. 
Clinical legal education (by way of law clinics) trains law students in the spirit of social justice and public service, and provides desperatelyneeded legal services to poor communities and underprivileged persons. Law clinics serve to fill a gap not adequately addressed by governmental legal aid programmes, poverty and other factors created by issues of governance that deprive ordinary persons of legal protection.

\section{Link between access to justice through clinical legal education, governance and development}

The intervention by legal clinics in providing legal aid, advice and access to justice to indigent persons in Nigeria has no doubt brought relief to a group of Nigerians who otherwise would not have had access to justice due to the insufficiency of funds and the inadequacy of legal aid facilities provided by government. Access to justice contributes to an enabling environment for achieving the MDGs. It can spur economic growth and help to create a safe and secure environment. These clinics are known to be effective institutions that supplement the work of the legal aid programmes of the government in protecting the rights of people, therefore promoting good governance and contributing to human development.

The author agrees with Kofi Annan, a former United Nations Secretary-General, that good governance is perhaps the most important factor for promoting development. ${ }^{41}$ To further buttress the point on the effectiveness of legal clinics in promoting access to justice, the government has given backing to the existence of these clinics. Section 17 of the 2011 Act authorises the Council to collaborate with or otherwise engage the services of nongovernmental organisations (NGOs) and law clinics engaged in the provision of legal aid or assistance to persons who are entitled to legal aid. Public interest lawyering is a development that emerged in the Nigerian legal system in 2005. Rokosh et al state that the term 'public interest law' was widely adopted in the United States of America in the 1960 s. $^{42}$ Between 1960 and 1970, young graduate lawyers sought to make themselves and the law profession relevant by having an impact on society on social issues. ${ }^{43}$ The term was adopted to distinguish these lawyers from the "'corporate adjuncts" referred to by Brandeis'. ${ }^{44}$ According to the Network of University Legal Aid Institutions (NULAI) in Nigeria, public interest lawyering is a process of legal empowerment aimed at capacity building of everyday people

41 United Nations University Policy notes world governance assessment (WGA) (2002) http://archieve.unu.edu/p\&g/wga/index.html (accessed 22 June 2014).

42 E Rekosh et al (eds) Pursuing the public interest: $A$ handbook for legal professionals and activists (2001)

43 As above.

44 As above. 
towards using the law and its institutions to bring about social change. ${ }^{45}$ It is not disputed that the law and legal process can be used effectively in the public interest for the enforcement of social rights.

The emergence of legal clinics is to supplement governmentestablished legal aid centres and not to replace them. The activities of legal clinics (in the form of counselling, legal education, legal support in diverse ways, and providing all other forms of legal services to members of the community who are in dire need) provide an avenue for pro bono and volunteering work by legal practitioners and training of law students as future public interest lawyers through training as para-legals. The engagement of law students in clinical work can help to alleviate poverty and injustice in the community. Paralegals in legal aid clinics contribute in no small measure to social and economic development. The form of aid which legal aid clinics give to existing legal institutions is vital to good governance. Public interest lawyering, as provided for in legal aid clinics, therefore, remains a veritable tool for the lawyer to bring about good governance, accountability, quality and responsive leadership in governance. ${ }^{46}$ Public interest lawyering is an important tool in the legal protection of human rights. ${ }^{47}$

To fully achieve the MGDs by 2015, access to justice for the poor must continue to be properly addressed and the creation of more legal clinics is an effective way of intervention.

\section{Access to justice: Role of the University of Ibadan's Women's Law Clinic}

Like many law faculties in Africa, the Law Faculty at the University of Ibadan, Nigeria, for many decades adopted the traditional lecturing method to impart legal education to students. This entailed the use of theoretical teaching methods with little or no attention to practical aspects. However, embracing clinical legal education at the University of Ibadan may be traced back to the All-African Colloquium on Clinical Legal Education which took place in Durban, South Africa, from 23 to 28 June 2003, where university-based clinics were introduced. The meeting brought together clinical teachers from long-established law clinics in Kenya, South Africa and in Zimbabwe.

45 Peace and Collaborative Development Network 'Public interest lawyering and clinical legal education' 19 March 2012 http://www.internationalpeaceand conflict.org/profiles/blogs/public-interest-lawyering-and-clinical-legal-education? xg_source=activity\#.VbP_FZ-D7IU (accessed 25 July 2015).

46 A Adedimeji 'Nigeria: Judicial activism and public interest litigation' Daily Independent 13 August 2009 http://allafrica.com/stories/200908130402.html (accessed 22 June 2014).

47 CE Obiagwu Promoting economic, social and cultural rights using domestic legal mechanisms (2003). 
Kenya introduced practical skills into its legal education as early as 1994, with the establishment of the Faculty of Law at Moi University. Also, participants from the then newly-established clinics in Mozambique and Sierra Leone and prospective faculties interested in establishing clinics attended the colloquium. At the time, the Law Faculty of the University of Ibadan fell in the latter category.

After the Durban meeting in June, an NGO known as Network of University Legal Aid Institution (NULAl, Nigeria) was established in October 2003. This is an association of university law clinics promoting clinical legal education, legal aid and access to justice. NULAl has developed a clinical legal education (CLE) curriculum for Nigerian university law faculties/clinics and this curriculum was introduced as part of the undergraduate LLB programme in the 2008/ 2009 session. The Law Faculty of the University of Ibadan is a registered member of NULAl.

In February 2004, NULAl, in partnership with the Open Society Justice Initiative, hosted the first Nigerian clinical legal education colloquium, where participating law faculties supported the introduction of clinical legal education in Nigeria. At the meeting it was resolved, amongst other issues, that law faculties would facilitate the introduction and sustainability of clinical legal education in Nigeria.

\subsection{Conception of the Women's Law Clinic}

The idea of the Women's Law Clinic (WLC) at the University of Ibadan is closely linked to the need to reform legal education, the notion of the development of the justice system and the promotion of human rights in relation to access to justice for vulnerable groups. In respect of the last aspect, the aim is basically to pursue a social justice goal. There was a need to strengthen access to justice through the use of the 'informal sector' to enhance the reach and effectiveness of, and compliance with, human right standards. This was the whole idea behind the conception of the WLC, namely, to bring about greater social justice to indigent, poor or vulnerable communities.

\subsection{Birth of the Women's Law Clinic}

While some university clinics have relatively long histories, others have existed only a few years. The WLC was formally inaugurated on 18 July 2007. It is a law school-based, in-house clinic with its main office located in a separate building within the Law Faculty of the University of Ibadan. Due to the large clientele and the expansion of the access to justice programme, the WLC opened an annex in a property bequeathed to the Faculty in the Ibadan suburb approximately four kilometers away from the University's main campus. With the opening of the annex, the WLC has made legal services more accessible to more groups of women. It is a specialised clinic, in the sense that it concentrates on women. The clinic started by offering legal services in the areas of human rights and family law, 
which are in fact very wide areas, and has since expanded to accommodate other areas of law.

One of the goals of the WLC is to provide legal services to less advantaged women in society, that is, to serve a disadvantaged sector of the community, with the aim of improving the lives of women, securing justice, and advancing civil, political, economic, social and cultural rights. In Nigeria, with a population of over 150 million people, no adequate state-run legal service programme exists. Marginalised persons, including women and particularly indigent women, suffer. The WLC and other law clinics are often the only options available to these women.

The WLC is a walk-in clinic operating from Mondays to Fridays, except on public holidays, when the hours are from 09:00 to 16:00. The work at the WLC involves personal sacrifice and commitment to the cause of justice and humanity, for the benefit of victims or vulnerable persons. It is a public service with no remuneration in monetary terms.

\subsection{Case study in the Women's Law Clinic: Access to Justice Programme}

The Access to Justice Programme is aimed at contributing to improving legal education, the training of law students as paralegals, imbibing in them a public lawyering interest, providing legal aid and representation to the indigent population, and improving research on access to justice as it affects women in Ibadan, a big city in the southwest of Nigeria.

A few cases, randomly selected from cases handled in the Clinic, are used in the case study below.

\subsubsection{WLC/CAS/023}

The complainant approached the Clinic on 13 February 2008 for assistance in enforcing the judgment of a grade C customary court that ordered her husband to pay a certain amount for the maintenance of their children, an order the husband refused to carry out.

Action taken: On 4 July 2008, the WLC wrote to the court registrar requesting enforcement of the judgment on behalf of the client. The WLC further summoned the husband to the clinic to educate and counsel him on the implications of not carrying out the court order. The husband came to the clinic and after discussions with him he agreed that he would deposit the monthly allowance at the WLC and also make provision of food.

Remarks: The husband kept his promise and after a few months of compliance, a more convenient arrangement was made by the parties. The case file was closed.

The complainant in this case approached the WLC because she could not afford the fees of a lawyer because of her indigent position. 
Nigeria is a patriarchal society, and this fact, alone, puts women in a disadvantaged position. In order for the complainant to exercise her legal right to claim maintenance for the upkeep of herself and her children, the intervention of a legal institution was required for the enforcement of the court order. The award of money by the customary court without ensuring enforcement is an injustice to the complainant. The indigent position of the complainant denied her access to justice, coupled with the non-compliance by her husband with the order of court. Additional costs in terms of money and time would have been a burden on the complainant going back to the customary court. The intervention of the WLC went a long way towards assisting the complainant to protect her interests and to exercise her legal rights. In addition, the husband, through counseling, was able to meet his obligations and the couple, through mediation, settled their differences to the extent that they could come to a consensus on the way forward a few months after the intervention of the WLC.

\subsubsection{WLC/CAS/25}

On 14 February 2008, a client came to the WLC to report a case of neglect of fatherly responsibility against a legal practitioner. She expressed the fact that she feared that she would be deceived by the respondent as she could not stand up against him due to his position as a lawyer. The WLC counselled her as to her rights and the legal position.

Action taken: The legal practitioner refused the invitation to come to the WLC. However, he telephoned the WLC and intimated to the Clinic that steps had been taken concerning the case and that an agreement had been concluded with the client. The client was contacted and she confirmed that she was satisfied with the agreement with the lawyer and that she would prefer the case to be closed.

Remarks: The client expressed her appreciation and thanked the Clinic for the immediate intervention and the explanation regarding her rights. She promised to inform other women in her neighbourhood about their rights and about the Clinic that protects the helpless.

Access to justice is seeking and obtaining a remedy without fear. The complainant in this case had no trust in the legal system because of her husband's legal profession. The Clinic allayed the fears of the complainant through counselling and education, which the court might not have had the time to do. At the Clinic she could exercise her right to information regarding the Nigerian legal system, and through the intervention by the Clinic, the case was resolved. 


\subsubsection{WLC/CAS/112}

The client, a widow, approached the Clinic on 20 April 2010 complaining that her in-laws were trying to deceive her by depriving her of the property her late husband had left to her and her children. She alleged that her daughter was one of the next-of-kin, but her brother-in-law was attempting to change it and to substitute his own name to enable him to collect the letter of administration. She alleged that her brother-in-law did so because she could not afford a lawyer.

Action taken: The WLC immediately contacted the office of the late husband to confirm the true status of the document. Upon confirmation that the client was correct, a letter was written on her behalf to the appropriate probate registry entering a caveat on the granting of the letter of administration to the brother-in-law. The WLC then sent a letter to all parties concerned with the aim of settling the mater amicably. The parties were counselled on their rights in accordance with the law. The brother-in-law was advised to return all documents to the widow. He refused to do so and the matter was referred to a lawyer.

Remarks: The WLC followed up the case on behalf of the widow and ensured that the documents were returned to her.

Widowhood is a multi-faceted tragedy for a woman under Nigerian customary law. Traditional practices during widowhood, which are deeply embedded in many Nigerian societies, can generally be described as cruel and inhuman. A widow is usually discriminated against after the death of her husband and subjected to humiliating burial rites and mourning practices under the guise of tradition. Nwadinobi says at the death of a spouse, a widow is dethroned, defaced and disinherited. ${ }^{48}$ Elaborating upon these phrases, Nwadiobi explains that a widow is disinherited and dispossessed of all the property she had acquired together with her husband. ${ }^{49}$ The concept of a widow under the traditional system is that of a defenceless, vulnerable, marginalised and invisible being. The above discussion explains the plight of the complainant who approached the Clinic. The needs of the complainant, coupled with widowhood, place her in a position where, without intervention, she may be disenfranchised. The intervention of the WLC enabled the complainant to have access to justice without any financial strain, and brought about the desired relief which otherwise would have been impossible. Traditionally, women are not expected to own any property. A major challenge the complainant would have faced, had it not been for the intervention of the WLC, was a show-down with her in-laws and an allegation that she had been responsible for the death of her husband so that she could inherit his property. This allegation arises from a misconception

48 E Nwadinobi 'Fighting back against prejudice and discrimination' paper presented at the Widows Without Rights Conference, London, 6-7 March 2001.

49 As above. 
that all property in the family belongs to the man who is the head of the family, notwithstanding the fact that women bear a large burden and are legally involved in the economic enterprise of the family, in addition to being responsible for childbearing and taking care of the household..$^{50}$ The intervention of the WLC enabled the voice of the complainant to be heard and allowed her to participate in a matter affecting herself. These are the characteristics of good governance.

\subsubsection{WLC/CAS/139}

The client, a widow, approached the WLC on 7 January 2011 complaining that her influential father-in-law was attempting to take her husband's property from her.

Action taken: The WLC immediately wrote to the father-in-law summoning him to the Clinic. The meeting at the Clinic did not materialise as other family members became involved in the matter and the client requested that it should be resolved amicably within the family.

Remarks: The case file has since been closed.

The above case is similar to the case in WLC/CAS/112 discussed above. The only distinguishing factor was that the WLC did not pursue the case to its logical conclusion. The end result of the case could not be determined as the client requested that the case be amicably settled with the family. The WLC could not ascertain whether the client had been intimidated into withdrawing the case or not.

\subsubsection{WLC/CAS/198}

The client, a petty trader, approached the WLC on 25 June 2012 requesting the Clinic to assist her to collect her husband's entitlement which her in-laws were contesting.

Action taken: The WLC requested the client to provide the names of the family members who were contesting her entitlement. The client has since shown no interest in the case.

Remarks: The case file has been closed.

This case, like the case of the widow in case WLC/CAS/139, was terminated because the client did not show any further interest in the case when the WLC wanted to take steps to access justice on her behalf. There can be no access to justice when a member of a marginalised group, such as the client in the above case, fears the system. In all probability, this was the position of the client in this case.

50 O Bamgbose 'The Nigerian woman under the traditional system' (2012) (unpublished paper). 


\subsubsection{WLC/CAS/225}

The client, an elderly retiree, approached the WLC on 11 March 2013 complaining about the non-payment of house rental by the respondent, her tenant.

Action taken: The WLC wrote to the respondent, who refused to cooperate with the clinicians in settling the debt owed to the client. The WLC therefore contacted the employer of the tenant informing him of the tenant's attitude. With the intervention of the employer, the respondent gave an undertaking in writing to pay the client all monies owed to her.

Remarks: The Clinic ensured that all monies owed was paid through the clinic to the client.

The above case may be understood in the context of the position of pensioners in Nigeria. The delay in payment and often non-payment of pension money as and when due place pensioners in a serious predicament and render them vulnerable. The position of the client in this case may, therefore, be the denial of her source of livelihood from the government and her tenant. The case complained about was the refusal by the tenant to pay rent. The position of the client in this case would have made it difficult for her to pursue a case in a formal court because of expensive legal fees. The age of the client, the tedious court process and the legal fees were all factors that would have denied the client access to justice. The intervention of the WLC brought the client the desired relief and protected her interests.

\subsubsection{WLC/CAS/269}

On 19 November 2013 the client, a young school teacher, was brought to the Clinic by her mother to report the forceful removal of their daughter and granddaughter by the respondent, who had earlier, during pregnancy and the birth of the child, denied paternity. The client learnt about the Clinic through a staff clinician.

Action taken: The WLC wrote to the respondent, but he was evasive and did not present himself at any of the meetings as he alleged that he was too busy with his boss who was an influential politician. He therefore sent elders of his family to represent him. Due to concern about the welfare of the child, who it was alleged was not being adequately taken care of, the matter was reported and transferred to the state social welfare office. Due to the concerns of the client and her mother that justice would not be served, the WLC followed up the case at the social welfare office. At the social welfare office, the matter was taken to the Juvenile Court with the WLC in attendance representing the client. The court ordered that it was in the best interests of the child to be with the client and the child was handed over to the client, while the respondent was ordered to pay for the maintenance of both mother and child. The father was given visiting rights. 
Remarks: The mother and child are doing well and the child has returned to her former school. The case file has been closed.

The position of the Nigerian child vis-à-vis the mother is succinctly described in the following statement by President Robert Mugabe: ${ }^{51}$

The child born of a woman despite the nine months spent in her womb was never hers by customary right of ownership. The child remained her child only as long as the marriage between her and her husband was good.

For the client in this case to be said to have had access to justice, she must have confidence in the system whereby her case is to be resolved. The influential position of her husband in society caused her to lose confidence in the legal system which should have afforded her protection. The intervention of the WLC gave her the confidence necessary to go through the legal process.

Apart from the cases discussed above, there are a few cases labelled 'classified cases', which are very sensitive in nature. They include cases of rape, indecent assaults on children and child adoption. These cases are followed up by clinicians from the WLC together with other units inside and outside of the University. These units include the police, hospitals and state social welfare and legal aid offices which are government units, partnered by NGOs such as the Nigerian Bar Association (Ibadan Branch) and the International Federation of Women Lawyers (FIDA, Nigeria). The WLC is linked with other units within the University to provide services to women who are not University staff but are within the catchment area of the Clinic. ${ }^{52}$ The units include the social work, guidance and counselling and psychology departments of the University of Ibadan. There are instances of referrals from governmental units to the WLC. Children from juvenile courts and their parents are sometimes referred to the WLC for counselling. This has been attributed to the insufficient number of qualified social workers in government service.

A descriptive analysis of the cases above and the services rendered by the WLC reveals that the Clinic maintains a relationship and collaboration with government and NGOs. ${ }^{53}$ It is thus clear that legal aid clinics play a prominent role in access to justice. The WLC also engages private legal practitioners in the community to provide pro bono services.

51 Opening speech by Robert Mugabe, Prime Minister of the Republic of Zimbabwe, President of the Zimbabwe African National Union (Patriotic Front) May 1979 in 'Liberation through participation: Women in the Zimbabwean revolution. Writings and documents from ZANU and the ZANU Women's League' http:// freedomarchives.org/Documents/Finder/DOC52_scans/52.Liberationthroughparti cipation.zanu.pdf (accessed 25 July 2015).

52 Women's Law Clinic newsletter: History of the Clinic (2011) Women's Law Clinic, Faculty of Law, University of Ibadan Newsletter 7.

53 O Olomola \& O Bamgbose 'Collaborating with other disciplines: Best practice for legal clinics - A case study of the Women's Law Clinic, University of Ibadan Nigeria' (2013) 19 International Journal of Clinical Legal Education Practice 355. 
It is also clear from the case studies that the WLC takes a holistic approach to the representation of indigent women. The Clinic provides legal and counselling services, educates women regarding their rights, and encourages dispute resolution mechanisms as opposed to litigation. The WLC also takes cognisance of the culture of the people in providing services to the client, therefore maintaining the integrity of the community and ensuring its legitimacy. ${ }^{54}$ The WLC tries as much as possible to settle disputes without resorting to filing actions in court. This is because of a cultural saying amongst the Yoruba people of the south-west of Nigeria which, when literally interpreted, means that 'you do not take a person to court and you ever remain as friend'.

A few testimonials extracted from the newsletter of the WLC confirm that the services rendered by the Clinic have gone a long way towards improving the lives of women in the community. A female client said: 55

The clinic has assisted me on several occasions with my domestic problems. I appreciate the fact that the clinicians were never tired of my numerous complaints.

Another female client said: ${ }^{56}$

The clinic helped me and my children during my crisis period. I rate the clinic with a pass mark of 95 per cent.

\section{Conclusion}

There is no doubt that there are concerted efforts by the government in dealing with women's access to justice issues in lbadan. However, these efforts lack sufficient funding. ${ }^{57}$ Another problem impeding the government's efforts is inadequate personnel to tackle the number of cases. The referrals of cases from governmental agencies to the WLC mentioned in the case study above attest to this fact. Government agencies lack experts to focus on research that would clarify the underlying issues affecting access to justice. This problem is solved by legal aid clinics, such as the WLC, that do research in this area. These were some of the challenges facing legal institutions in Nigeria.

The establishment of campus-based law clinics in Nigeria, of which the WLC is one, through the introduction of clinical education into the curriculum of the Nigerian law school and law faculties, has improved the rule of law and strengthened legal institutions. It has proved to be a way of improving access to justice for women, in

54 O Bamgbose \& O Olomola 'Clinical legal education and cultural relativism - The realities in the 21st century' (2014) 20 International Journal of Clinical Legal Education 579.

55 Women's Law Clinic Newsletter (n 52 above).

56 As above.

57 OECD Guideline Series (n 26 above). 
particular, in Nigeria. The services rendered by the existing 18 campus-based law clinics have gone a long way towards supporting the work of government in different parts of Nigeria. With the adoption of clinical legal education curricula through the establishment of law clinics at many other law faculties in Nigeria, and the legal clinics supplementing the efforts of government, the legal system will be more effective, which is evidence of good governance and development in Nigeria. 